\title{
Cultural Heritage in Pekraman Gelgel Village: From Text to Context
}

\author{
I Made Mardika; Anak Agung Gede Raka; I Made Suwitra \\ \{dikamar73@gmail.com\} \\ Program Pascasarjana Universitas Warmadewa
}

\begin{abstract}
A study on cultural heritage landscape is essential in compiling the cultural history of the Gelgel kingdom. The purpose of this study is to carry out an inventory, identification, classification, and description of cultural heritage in the Pekraman Gelgel Village. It aims to construct a holistic history of the kingdom, relying on a variety of cultural texts and contextual analysis to produce a meaningful historical view. To achieve these targets, three eclectic theories are used, including archeological, semiotic and hermeneutic. Also, this research uses a qualitative method with a cultural study approach. The study instrument was the researcher with various tools, including interview guidelines, field data recording cards, digital cameras, drones and mobile phones. Importantly, observation, indepth interviews with informants, and documentation techniques were used for data collection. The results showed that there are rich and varied cultural heritage in the Gelgel kingdom era XIV-XVI AD. The diversity of cultural heritage forms can be grouped into five, including 3 inscriptions, 45 temples, megalithic tradition and classical statues, 5 performance arts, 4 handicrafts, and 3 Islamic cultures. Contextualization of Cultural Heritage is the basis of developing the history of the Gelgel Kingdom Period according to the structure of the palace city and socioreligious life. The inventory of cultural heritage forms uploaded on the website, and the complete construction of Gelgel's cultural history, can be packaged as a tourist attraction (tourist village).
\end{abstract}

Keywords: cultural heritage, text, context, tourist villagea

\section{Pendahuluan}

Dalam sejarah kebudayaan Bali abad XIV_XVI Masehi Desa Pekraman Gelgel adalah pusat pemerintahan kerajaan yang dikenal dengan nama Sweca Linggarsa Pura. Keraton Gelgel digambarkan dengan struktur terpusat yang dikelilingi oleh pemukiman para pembesar kerajaan (Wirawan, 2008). Gambaran Kota Sweca Pura ini didasarkan pada teks yang dimuat dalam Babad Dalem yang dapat ditemukenali dari identifikasi nama-nama banjar yang ada di kawasan Desa Pekraman Gelgel (Sutaba, dkk. 2007). Akan tetapi, sumber teks tulis yang dibuat belakangan tersebut belum mampu mengungkatkan gambaran kehidupan budaya masyarakat masa Gelgel secara menyeluruh. Sehingga, sejarah kebudayaan Jaman Gelgel masih bersifat fragmentaris dan kurang ditunjang oleh data yang lengkap. 
Sebagai pusat kerajaan, Desa Pekraman Gelgel memiliki kekayaan warisan budaya yang cukup beragam. Jejak-jejak tinggalan budaya masa lalu yang ada terdiri atas bangunan suci pura, prasasti, permukiman kelompok masyarakat, benda-benda sacral, maupun barang-barang seni. Warisan budaya berbentuk bangunan pura yang tergolong 'besar' di Desa Pekraman Gelgel berjumlah lebih dari 24 pura, terdiri atas Pura Kahyangan Jagat, Pura Dang Kahyangan, Pura Kahyangan Tiga maupun Pura Pusat Kawitan atau pura yang bersifat genealogis (Mardika, 2018). Demikian pula cagar budaya berupa prasasti banyak disimpan oleh penduduk sebagai barang pusaka yang disucikan. Tinggalan budaya lainnya adalah benda-benda seni budaya seperti Gelung (mahkota) Ratu Panji yang disimpan di Pura Pusering Jagat Gelgel, Senjata Tombak Oncer Ganda di Pura Bale Tumbak, dan Seni Wayang Wong di Pura Bale Batur Kamasan. Di Desa Kamasan sendiri terdapat komunitas perajin logam (pande emas, perak, besi) dan pelukis wayang tradisional Kamasan, sebagai kelanjutan dari tradisi masa kerajaan Gelgel (Wirawan, 2008).

Gambaran keanekaragaman dan kekayaan cagar budaya di Desa Pekraman Gelgel memberikan indikasi tentang lanskap warisan budaya yang ada di kawasan Gelgel. Kenyataan ini dapat dibandingkan dengan situs tinggalan purbakala di sepanjang wilayah Pejeng-Bedulu yang juga pernah menjadi pusat Kerajaan dan peradaban Bali Kuno (Raka, 2018). Situs cagar budaya tersebut penting artinya dalam mengkonstruksi sejarah kebudayaan pada masa kerajaan Bali Kuno (Ardika, 2018). Selain itu, yang juga tidak kalah penting artinya dalam mengungkap latar kehidupan budaya pada masa lalu adalah cerita-cerita rakyat, mitos, maupun memori kolektif masyarakat local. Sering kali ceritera-cerita yang berkembang di masyarakat dapat dijadikan rujukan dalam menggambarkan kembali kehidupan sosial budaya yang ada di suatu tempat. Akan tetapi, data penunjang sejarah tersebut belum digunakan dalam mengkontruksi sejarah kerajaan masa Gelgel dengan semestinya. Berdasarkan latar belakang di atas, tujuan penelitian ini adalah untuk melakukan identifikasi, klasifikasi, dan mendeskripsikan bentukbentuk warisan budaya yang ada di Desa Pekraman Gelgel; dan untuk mengkontruksi sejarah kebudayaan pada jaman kerajaan Gelgel (Abad XIV-XVI Masehi).

\section{Metode}

Lokasi penelitian ini dilakukan di Desa Pekraman Gelgel Kecamatan Klungkung Kabupaten Klungkung Bali. Secara administratif Desa Pekraman Gelgel terdiri atas 3 desa dinas meliputi Desa Kamasan, Desa Tojan, dan Desa Gelgel, serta 28 banjar adat. Desa Pekraman Gelgel dikenal sebagai kota Sweca Linggarsa Pura yang pada abad XIV-XVI menjadi pusat keraton Raja sekaligus sebagai ibukota Kerajaan Bali. Sesuai dengan karakteristik penelitian kualitatif maka instrumen utama penelitian ini adalah peneliti sendiri. Dalam pelaksanaannya, juga didukung oleh instrumen menunjang seperti: form pencatatan, alat ukur, pedoman wawancara, dan alat dokumentasi audio visual (camera digital, drone), digitalisasi berupa smartphone. Teknik pengumpulan data yang diterapkan dalam penelitian ini meliputi: observasi lapangan, wawancara berfokus dengan sejumlah informan kunci, dan teknik dokumentasi. Data yang berhasil dikumpulkan diolah dan diorganisir melalui klasifikasi dan sortir data untuk selanjutnya dilakukan analisis data. Metode yang digunakan dalam penelitian ini adalah metode deskriptif kualitatif dan juga menggunnakan metode kuatitatif. Selain itu, dilakukan juga analisis kontektual untuk mencermati hubungan keterkaitan antara data dalam lingkup kawasan tertentu. 


\section{Hasil Dan Pembahasan}

Berdasarkan tujuan dan hasil penelitian yang dilakukan, maka diperoleh hasil analisis yang dijabarkan di bawah ini.

\subsection{Bentuk-bentuk Warisan Budaya di Desa PekramanGelgel}

Kerajaan Gelgel dimulai sejak perpindahan pusat kerajaan di Samprangan menuju Gelgel sejak era pemerintahan Dalem Ketut Ngulesir (1380-1400) hingga pusat pemerintahan dipindahkan ke Klungkung tahun 1686 (Sidemen, dkk, 1983:22-36). Masa Gelgel yang berlangsung sejak abad XIV-XVI Masehi meninggalkan banyak warisan budaya berupa tinggalan-tinggalan masa lalu baik berupa prasasti, bangunan suci pura, seni arca, tradisi dan memori kolektif masyarakat. Semua warisan budaya tersebut merupakan teks yang dapat dijadikan sumber sejarah kebudayaan guna merekonstruksi kembali proses-proses budaya yang terjadi pada masa itu.

Menarik untuk diungkapkan adalah tinggalan dua lembar prasasti yang tersimpan di Pura Ibu Kawitan Pasek Gelgel Bendesa Tangkas Kuri Agung. Pura Ibu Kawitan ini terletak di sebelah selatan Pura Dasar Buana Gelgel yang menyimpan dua lembar prasasti yaitu prasasti tembaga dan prasasti perak. Kedua lembar prasasti tersebut oleh masyarakat setempat disebut pariagem yang dikeluarkan oleh raja Gelgel Dalem Waturenggong. Di Pura Dalem Tugu juga terdapat sebuah prasasti yang dikeluarkan oleh raja untuk Arya Kebon Tubuh yang sampai sekarang masih disungsung di Pura tersebut.

Sebagai pusat kerajaan Gelgel meninggalkan warisan budaya berupa pura yang cukup banyak dan tersebar. Ditinjau dari pengelompokan jenis pura, warisan budaya pura yang ada di Desa Pekraman Gelgel terdiri atas pura yang berstatus pura umum Kahyangan Jagat atau Dang Kahyangan, pura bersifat genealogis berhubungan dengan soroh/keturunan, pura territorial yakni kahyangan tiga, dan pura fungsional (pura subak), pura segara dan Pura Melanting. Di Desa Dinas Tojan terdapat 7 buah pura yang sebagian terbesar merupakan pura genealogis. Pura dimaksud adalah Pura Manik Bingin, Pura Penataran Pande Kori Batu, Pura Dalem Pemuteran, Pura Kawitan Pasek Toh Jiwa, Pura Kawitan Pasek Salain, Pura Taman Sari dan Pura Batu Klotok. Di Desa Kamasan terdapat 7 pura besar yang juga sebagian terbesar merupakan pura yang bersifat genealogis. Dari batas utara desa hingga selatan terdapat antara lain Pura Tirta Segening, Pura Puseh Katyagan, Pura Bale Batur, Pura Batu Lepang Kamasan, Pura Kawitan Arya Pering, Pura Penataran Pande Kamasan, dan Pura Kawitan Arya Kenceng. Di Desa dinas Gelgel terdapat 32 pura yang tersebar di masing-masing banjar. Pura-pura yang terdapat sesuai wilayah banjar dari arah barat ke timur adalah sebagai berikut ini. Di Banjar Jero Kapal terdapat dua pura yang berasal dari masa kerajaan Gelgel yaitu Pura Tampak Meles dan Pura Puseh Nyuhaya. Di banjar Pancoran terdapat satu pura yakni Pura Dalem Guru. Pura Dalem Guru bukan berstatus sebagai pura territorial (Pura Kahyangan Tiga) melainkan sebagai pura pemaksan yang disungsung oleh warga di lingkungan wilayah Banjar Pancoran dan Banjar Jerokapal. Di Pura ini juga terdapat petapakan Barong Ket yang disakralkan, hanya ditarikan pada saat odalan. Di Banjar Jero Agung Kaler terdapat 3 pura, yaitu: Pura Penataran Jero Agung, Pura Mas Meles dan Pura Kawitan Gedong Arta. Pura Penataran Jero Agung besar kemungkinan sebagai pura/ mrajan Raja Gelgel. Kecendrungan ini diindikasikan oleh nama pura penataran, lokasi pura, dan kekunoan tinggalan arkeologis. Di Banjar Jero Agung Kelod dua pura yang merupakan satu kesatuan yang berhubungan dengan keturunan Arya Kuta Waringin yaitu Pura Penyimpenan dan Pura Dalem Tugu.

Di Banjar Tangkas Gelgel terdapat tiga pura yang berhubungan erat dengan masa Gelgel, yaitu: Pura Ibu Kawitan Pasek Gelgel Bendesa Tangkas Kori Agung, Pura Wrehapsari, dan Pura 
Batu Tumpeng. Pura Ibu Kawitan Pasek Gelgel cukup erat kaitannya dengan masa Gelgel yang memberitahukan tentang perintah raja Dalem Waturenggong mengangkat I Gusti Dauh Baleagung sebagai sekretaris Raja dan menyelenggarakan pengelolaan Hyang Gung Ugung (Pura Dasar Buana Gelgel). Setelah Beliau menjadi pendeta, kemudian tugas pengelenggaraan Pura Kahyangan Utama tersebut diberikan kepada Ki Pasek Gelgel beserta keturunannya (Tarawiguna, 2019). Kedua, terdapat prasasti berupa lontar yang memuat tugas Pasek Gelgel sebagai pemangku (Jan Bangul) Pura Dasar Buana secara turun-temurun. Bahkan menurut informasi penglingsir pura (I Nengah Tangkas, 78 tahun) di kompleks tempat tinggal pemangku pernah terdapat sebuah bangunan yang khusus diperuntukan bagi Dwagung (sebutan untuk Raja Klungkung). Bangunan ini digunakan oleh raja jika ada upacara di Pura Dasar Buana Gelgel.

Pura Wrehapsari merupakan pura kawitan bagi keturunan I Gusti Arya Dauh. Tokoh ini menjabat sebagai sekretaris raja sehingga acapkali melakukan pembicaraan yang penting dan rahasia. Tempat untuk melakukan pembicaraan yang tergolong penting dan rahasia adalah di Mrajan beliau yakni Pura Wrehapsari. Wrehapsari berarti inti sari pembicaraan atau pembicaraan yang sangat penting dan rahasia. Pura Wrehapsari disungsung oleh keturunan I Gusti Dauh Baleagung. Di Banjar Pegatepan terdapat 7 pura warisan budaya masa Gelgel, yaitu: kompleks Pura Dasar Buana, meliputi Pura Pusering Jagat, Bale Agung, dan Pura Yasa, Pura Kawitan Pulasari, Pura Dadya Agung Pasek Gelgel, Pura Merajan Hyang Api, Pura Dalem Segening dan Pura Merajan Lombok. Pura Dasar Buana sebagai pura terbesar di Gelgel merupakan kompleks pura yang dianggap sebagai Kahyangan Tiga Agung terdiri atas Pura (Dalem) Dasar, Pura Pusering Jagat (Pura Puseh) dan Pura Bale Agung. Di kompleks Pura Pusering Jagat Gelgel juga terdapat bentuk-bentuk warisan budaya yang cukup beragam, seperti: 77 buah fragmen arca perwujudan, 2 fragmen lingga, 2 buah arca perwujudan, 1 buah batu alam. Memperhatikan jenis-jenis warisan budaya yang ada di Pura Dasar Buana Gelgel jelas menunjukkan pura ini mengalami perkembangan budaya dari masa pra Hindu hingga masa Gelgel. Hal ini erat terkait dengan proses sejarah perkembangan Pura Dasar Buana yang diawali sebagai Pesraman Mpu Gana, menjadi pemujaan tri warga (Kesatria, Pasek dan Pande) hingga menjadi Parahyangan Kerajaan sekaligus sebagai pemujaan catur warga (Wirawan, 2008, Mardika, dkk. 2018).

Di Banjar Minggir terdapat empat pura yang berkaitan dengan Masa Kerajaan Gelgel yaitu Pura Dalem Prajurit, Pura Pasek Ciwa Gaduh, Dalem Digede Setra Bugbugan dan Pura Dalem Kerti. Sedangkan di Banjar Dukuh terdapat tiga warisan budaya berupa pura yang merupakan peninggalan Kerajaan Gelgel. Pura dimaksud adalah Pura Dalem Nyuhaya, Pura Dalem Gandemayu dan Pura Kawitan Sri Nayarya Kresna Kepakisan.

Tinggalan budaya berupa warisan karya seni budaya di Desa Pekraman Gelgel, diantaranya seni arca, seni pertunjukan, seni kerajinan, dan kesusastraan. Warisan budaya berbentuk seni arca cukup banyak ditemukan di Desa Pekraman Gelgel yang umumnya disakralkan dan tetap difungsikan sebagai media pemujaan oleh masyarakat (living monument). Bentuk-bentuk seni arca yang ditemukan berupa arca primitif dan kedok muka sebagai kelanjutan tradisi Megalitik seperti di Pura Penataran Jero Agung, Arca Dewa seperti arca Ganesa dan lingga, Arca perwujudan Betara/Betari, arca binatang dan berbentuk kala/raksasa sebagai penjaga (Dwara Pala).

Warisan budaya berupa seni pertunjukan antara lain: Wayang Wong terdapat di Pura Bale Batur Desa Kamasan, Barong Landung di Pura Taman Sari Kamasan, Barong Ket di Pura Taman Sari Tojan dan di Pura Dalem Guru Gelgel, Tombak Oncer Gande di Desa Bale Tumbak yang menjadi inspirasi Tari Baris Oncer Ganda, dan Gelungan Ratu Panji di Pura Pusering Jagat Gelgel.

\subsection{Sejarah Kebudayaan Kerajaan Gelgel: dari Teks ke Konteks}


Warisan budaya sebagai suatu teks budaya yang berada pada suatu bentang alam di Desa Pekraman Gelgel memiliki korelasi atau hubungan yang erat antara satu dengan lainnya. Polapola keterkaitan (konteks) antar warisan budaya inilah yang dijadikan basis dalam mengkonstruksi sejarah kebudayaan Masa Kerajaan Gelgel yang berlangsung dari Abad XIV sampai XVI Masehi. Sejarah kebudayaan yang hendak digambarkan difokuskan pada dimensi struktur kota Sweca Linggarsa Pura sebagai pusat pemerintahan/keraton raja yang berhubungan dengan kehidupan sosial religious magis masyarakat.

Berdasarkan indikasi warisan budaya yang dapat diidentifikasi, pusat Keraton Sweca Linggarsa Pura berlokasi di Banjar Jero Agung (Kaler dan Kelod). Warisan budaya pura yang menjadi penanda keraton adalah Pura Penataran Jero Agung yang tepat berada pada arah timur laut keraton. Di depan Pura Penataran Jero Agung terdapat pertigaan (Catuspata) sebagai ciri sebuah keraton. Memori kolektif masyarakat local menyebut lahan di sebelah utara Catuspata sebagai bencingah (alun-alun) yang identic dengan ruang terbuka (public) sebagai ciri keberadaan suatu keraton. Sebelah timur Pura Penataran Jero Agung sampai sekarang terdapat pasar sebagai kelengkapan suatu lanskap keraton. Di samping timur areal pasar berdiri kompleks Pura Dasar Buana Gelgel yang dijadikan pura 'kota' kerajaan Gelgel.

Struktur keraton Sweca Linggarsa Pura menunjukkan pola konsentris dengan keraton di Banjar Jero Agung sebagai pusatnya, yang lapis kedua dikelili oleh tempat tinggal pembesar kerajaan yang diindikasikan oleh keberadaan warisan budaya pura maupun nama banjar, subak maupun kelompok permukiman. Di sebelah utara kraton adalah karang kepatihan tempat tinggal patih Agung Krian Patih Nyuhaya. Nama patih ini tentu erat kaitannya dengan Pura Puseh Nyuhaya yang berlokasi di Banjar Jero Kapal, dan Pura Dalem Nyuhaya di Banjar dukuh. Di sebelah utara kediaman Nyuhaya adalah tempat tinggal Ki Gusti Tabanan (sekarang menjadi nama Banjar Tabanan) yang mendirikan Pura Kawitan Arya Kenceng, Ki Gusti Penataran dan Ki Gusti Pande yang ditandai dengan nama banjar (Pande) dan warisan budaya pura berupa Pura Penataran Pande Di sebelah barat keraton tepatnya di banjar Jero Kapal merupakan tempat tinggal Krian Asak. Tokoh ini boleh jadi yang mendirikan Pura Tampak Meles. Di sebelah selatan keraton adalah tempat tinggal Kyai Klapodyana (I Gusti Kebon Tubuh) yang mendirikan Pura DalemTugu. Di sebelah timurnya merupakan kediaman Arya Kanuruhan yang berputra Ki Gusti Tangkas yang sampai sekarang menjadi nama Banjar Tangkas. Di Sebelah selatan pasar adalah tempat tinggal Ki Gusti Penyarikan Dauh Bale Agung yang mendirikan pura bernama Pura Wrahapsari Demikian pula di sebelah timur pasar ( dangin peken) adalah tempat tinggal Ki Gusti Pegatepan yang sekarang menjadi nama banjar yakni Banjar Pegatepan. Ki Gusti Pegatepan membangun parahyangan yakni Pura Dalem Kerti. Di sebelah timur Ki Gusti Pegaten merupakan tempat penyimpanan Tombak Lascar Gelgel bernama Tombak Oncer Ganda. Lokasi ini menjadi nama banjar yaitu Banjar Bale Tumbak dan sekaligus sebagai nama tempat suci yakni Pura Bale Tumbak. Sekitar 300 meter ke arah timur dari Banjar Bale Tumbak merupakan tempat tinggal I Gusti Peminggir (menjadi nama Banjar Minggir) yang mendirikan tempat pemujaan untuk leluhur Arya Tan Kober bernama Pura Dalem Prajurit.

Selain penempatan kelompok pembesar kerajaan di sekeliling keraton yang berasal dari trah Arya (wong Majapahit), pada lapis ketiga ditempati oleh warga pasek dan Pande. Pasek Salahin dan Pasek Toh Jiwa tinggal di sebelah barat jero Kapal, yang sekarang ditandai dengan adanya warisan budaya Pura Kawitan Pasek Salahin dan Pura Kawitan Pasek Toh Jiwa di Desa Tojan. Pasek Gaduh yang tinggal di sebelah timur keraton tepatnya di Banjar Minggir yang ditandai oleh warisan budaya Pura Pasek Ciwa Gaduh. Trah Pande yang memiliki ketrampilan seni di bidang seni lukis wayang Kamasan bertempat tinggal di Banjar Sangging, bersebelahan dengan kelompok pande Pande Mas dan Perak yang berada di banjar Pande Mas yang erat terkait 
dengan warisan budaya Pura Bale Batur. Trah Pande Besi bertempat tinggal di banjar Pande dan mendirikan pura untuk pemujaan leluhur yakni Pura Penataran Pande.

Secara faktual Pura Dasar Buana Gelgel merupakan warisan budaya monumental yang terbesar di Desa Pekraman Gelgel yang berasal dari masa Kerajaan Gelgel. Kompleks Pura Dasar Buana memiliki kedudukan strategis jika dibandingkan dengan warisan pura-pura lainnya yang ada di Desa Pekraman Gelgel. Hal ini dapat dicermati dari dinamika sejarah perkembangan status Pura Dasar Buana Gelgel yang mengandung unsur politis dan sosio magis (Wirawan, 2008; Mardika, 2018). Pura Dasar Buana pada mulanya merupakan Pasraman dari Mpu Gana yang menurut teks-teks tradisional dianggap sebagai tokoh pasek dari Jawa (Pancaka Tirtha) yang berdiam di Gelgel. Pura Dasar kemudian dinaikan statusnya sebagai pura kerajaan (Kahyangan Jagat) pada era Raja Dalem Ketut Ngulesir. Pura ini dijadikan sebagai pura tri kahyangan kerajaan yakni Besakih sebagai Pura Gunung, Pura Dasar Buana sebagai pura Kota, dan Pura Batu Klotok sebagai Pura Segara. Dalam hal ini Pura Dasar Buana juga dipakai sebagai wadah pemersatu untuk pemujaan tri warga meliputi: warga Kesatria Dalem, warga Pasek, dan warga Pande.

Peningkatan status Pura Dasar sebagai Pura Kahyangan Jagat oleh Raja Dalem Ketut Ngulesir dapat dimaknai sebagai kebijakan politis. Pura yang sebelumnya hanya menjadi tempat pemujaan warga pasek kemudian dijadikan Pura Kerajaan memberikan efek psikologis dan penghargaan kepada warga pasek yang merasa dihormati sehingga timbul rasa bakti dan dukungan kepada raja. Dengan cara ini Raja telah melakukan tindakan politis dalam rangka menjaga loyalitas kepada kerajaan Sweca Linggarsa Pura. Demikian pula halnya kelompok Pande yang memiliki fungsi strategis sebagai pemasok peralatan dan teknologi penting untuk dirangkul. Oleh karena itu, Pura Dasar Buana dijadikan media sebagai tempat suci untuk mempersatukan trah tri warga yang ada di Bali. Selain itu, peningkatan status Pura Dasar Buana sebagai Pura Kahyangan Jagat juga mengandung makna religious magis bagi kerajaan Sweca Linggarsa Pura. Raja berupaya meningkatkan Seperti ditulis oleh Wirawan (2008: 18) sebagai berikut.

"Tekad Dalem Ketut Ngulesir agar terciptanya suasana Manunggaling Kawula Gusti dalam tahta kerajaan secara spiritual ditandai dengan pengakuan status Kahyangan Jagat Pura Besakih sebagai symbol atas (luhur), strukturnya berundak ke atas, sedangkan Pura Dasar diakui sebagai Kahyangan Jagat symbol bawah, dasar ing Jagat Bali yang strukturnya berundak ke bawah. Sekaligus menjadikan kompleks Pura Dasar terdiri atas Pura Dalem, Puseh dan Bale Agung sebagai Kahyangan Tiga kerajaan atau Kahyangan Tiga Jagat"

Dengan demikian kebijakan Raja Dalem Kresna Kepakisan terhadap Pura Dasar Buana dapat dipandang sebagai integrasi kekuasaan politik dengan relegius magis dalam upaya legitimasi pemerintahan dan kesejahtraan warga masyarakatnya.

\section{Kesimpulan}

Berdasarkan hasil dan pembahasan tentang Warisan Budaya di Desa Pekraman Gelgel dapat disimpulkan dua hal yaitu 1) bentuk-bentuk Warisan Budaya dari Masa Kerajaan Gelgel Abad XIV-XVI Masehi menunjukan jenis yang kaya dan beragam. Jumlah keragaman bentuk warisan budaya di Desa Pekraman Gelgel dapat dikelompokan menjadi lima jenis, yaitu: prasasti 3 buah, pura sebanyak 45, seni arca yang bercorak tradisi megalitik hingga arca masa klasik, seni pertunjukan sebanyak 5 jenis, seni kerajinan 4 jenis, dan kebudayaan islam 3 jenis. Karakteristik warisan budaya di Desa Pekraman Gelgel menampakkan kesinambungan dari tradisi megalitik, klasik hindu, dan majapahit yang berintegrasi membentuk kearifan lokal Bali. 2) 
kontekstualisasi Warisan Budaya di Desa Pekraman Gelgel menjadi basis dalam mengkontruksi sejarah kebudayaan Masa Kerajaan Gelgel menyangkut dimensi struktur kota keraton terkait dengan kehidupan sosio religious. Struktur kota keraton Sweca Linggarsa Pura memperlihatkan pola yang terpusat / konsentris. Kehidupan Sosial religious masyarakat berpusat di Pura Dasar dengan pura-pura sekelilingnya sebagai penyangga.

\section{References}

[1] Ardika, I Wayan. 2007. Pusaka Budaya dan Pariwisata. Denpasar: Pustaka Larasan.

[2] Dhana, I Nyoman. 2010. Revitalisasi Ideologi Tri Hita Karana Versus Ideologi Pasar pada Masyarakat Multikultur: Studi Kasus Pengelolaan Pura Subak Tegal di Perumahan Bumi Dalung Permai, Kuta Utara, Badung, Bali. Disertasi Program Kajian Budaya Program Pascasarjana Universitas Warmadewa Denpasar.

[3] Fox, David J. Stuart. 2010. Pura Besakih: Pura, Agama, dan Masyarakat Bali. Denpasar: Pustaka Larasan, Uayana University Press. Jakarta: KITLV.

[4] Geriya, I Wayan. 2000. Transformasi Kebudayaan Bali Memasuki Abad XXI. Denpasar: Dinas Kebudayaan Propinsi Bali.

[5] Mardika, I Nyoman, I Made Mardika, AAR Sita Laksmi. 2010. Pusaka Budaya: Representasi Ragam Pustaka dan Tantangan Konservasi di Kota Denpasar, Bali. Kerjasama Bapeda kota Denpasar dengan Pusat kajian Pariwisata dan Budaya Fakultas Sastra Universitas Udayana.

[6] Mardika, I Made, AAR Sita Laksmi, Ketut Sudrama. 2011. Cagar Budaya Bali: Menggali Kearifan Lokal dan Model Pelestariannya. Denpasar: Warmadewa University Press.

[7] Mardika, I Made. 2014. Identifikasi Bentuk-bentuk Tinggalan Purbakala Terkait Jejak Perjalanan Dang Hyang Nirartha di Kota Denpasar (Studi Pendahuluan). Laporan Penelitian Universitas Warmadewa Denpasar.

[8] Mardika, I Made; I Wayan Wesna Astara; Nyoman Sujaya. 2016. "Konstruksi Nilai Kearifan Lokal Perjalanan Dang Hyang Nirartha di Kelurahan Tuban dan Kota Denpasar" dalam Wicaksana Jurnal Lingkungan Lembaga Penelitian dan Pengabdian Kepada Masyarakat Universitas Warmadewa Vo. 25, No.2 hlm.203-215. September 2016.

[9] Menezes, Cornelio Aniceto. 2015. Strategi Pelestarian Kawasan Cagar Budaya di Pulau Serangan Bali. Skripsi Jurusan Arkeologi Fakultas Ilmu Budaya UGM Yogyakarta.

[10] Mirsa, I Gusti Ngurah, dkk. 1986. Sejarah Bali. Denpasar: Proyek Penyusunan Sejarah Bali Pemerintah Daerah Tingkat I Bali.

[11] Nawawi dan Hadari, 1992. Metode Penelitian Survey dan Pelaporan Penelitian. Yogyakarta: Mata Pena.

[12] Raka, Anak Agung Gede, 2018. "Situs Pejeng-Bedulu sebagai Pusat Peradaban Bali Kuno" Majalah Ilmiah Sudamala, No.2 Tahun 2018. BPNB Bali, NTB, NTT.

[13] Reuter, Thomas A. 2005. Custodians of the Sacred Mountaints (Budaya \& Masyarakat di Daerah Pegunungan Bali). Jakarta: Yayasan Obor Indonesia.

[14] Supartha, Wayan (ed). 2006. Mengenal Pura Sad Kahyangan dan Kahyangan Jagad. Denpasar: Pustaka Balipost.

[15] Sutaba, I Made; A.A.G. Oka Astawa; A.A.Bagus Wirawan. 2007. Sejarah Gianyar: dari jaman Prasejarah sampai Masa Baru-Modern. Pemerintah Kabupaten Gianyar Badan Penelitian dan Pengembangan Daerah. 
[16] Universitas Warmadewa, 2016. Rencana Strategis Lembaga Penelitian Universitas Warmadewa 2016-2020. Universitas Warmadewa Denpasar

[17] Wirawan, A.A. Bagus. 2008. Pura Dasar Sweca Linggarsa Pura: Kahyangan Jagat Kraton Ibukota Kerajaan Bali Pusat Agama Hindu di Nusantara Sejak Abad XIV. Pura Dasar Gelgel Kabupaten Klungkung. 